\title{
A Survey of Values Education and its Connection with Character Education
}

\author{
Dr. Nur Sılay \\ Koç University \\ E-mail: nsilay@ku.edu.tr
}

\section{Doi:10.5901/ajis.2013.v2n3p131}

\section{Abstract}

This paper attempts to examine briefly ideas on values education by various academics and how they see a connection between character education and values. It is an attempt to gather information from the results of different studies and present a synthesis systematically. Former studies mention direct links as values are natural parts of both values education and character education. Quite a number of scientists have noticed the vital role modeling of teachers as influential actors during the positive formation of their students' character. Moreover, the necessity of the intervention of universities for the character building of their own students is emphasized. As a result, it may be concluded that the mission of tertiary education is not only science but also education in a broad sense. The aim of values education is to help families and the society guarantee a better and more moral future. This objective is shared with character education and in this respect as well, the two currents have a common goal.

Keywords: Values education, character education

\section{Introduction}

The mission of higher education has been under discussion that has been continuing for decades. Scientists have different views regarding the responsibilities of higher education institutions and an agreement does not seem very likely to be reached in the near future. Some argue that universities' only duty is to prepare students for their careers whereas others believe that helping them become morally good human beings is as significant as providing them with instruction, which will be necessary once they graduate. The advocates belonging to the latter group defend the values education current, which has close links with character education. The two have several qualities in common as the teaching of values has an impact on the betterment of character. Sometimes the two terms are used interchangeably. Character improvement is realized by internalizing some basic values and acting with their guidance. Values education has been a topic of interest among many academics for several years now. Since it is closely intertwined with character education, researchers have studied both approaches quite often. This paper will attempt to look at the viewpoints of various academicians on values education and also point out the relationship between values education and character education. Therefore, as the aim is putting together and then evaluating different types of research findings, this paper should be considered a research review (Robson 2000).

\section{Values}

Cohen claims that in the center of most character education programs, there is the identification of core (consensus) values and these are most of the time character traits or values that have been developed so as to address the needs of the local district (Cohen 1995). He adds that the Aspen Declaration, the outcome of a character education conference in 1992, lists six values: respect, responsibility, trustworthiness, caring, justice and fairness, and civic virtue and citizenship. By concentrating on such basic values, educators aim at preventing political controversies that may stop character education in its tracks (Cohen 1995). Schwartz (2000) includes honesty, patience, and compassion among core values. He also mentions (2005) three discrete values: tolerance, freedom, and friendship. Lickona (1992 quoted in Cohen 1995) believes that some basic values have an objective basis which is not subject to individual interpretation and he continues that such values are vital for successful character education. He stresses that it is possible to teach the meaning and significance of these values (Lickona 1992 quoted in Cohen 1995). In addition, he argues that "But then you have to hold students accountable in some way so that when they violate the value, there is some kind of a correction, that they're held responsible for their behavior, and there's accountability in the system." (Lickona 1992 quoted in Cohen 1995). It has 
been expressed by educators that while education programs are being developed, values must be given importance (Varış 1978 quoted in Şirin 1986). An educated individual has values as well as knowledge and skills because just like them, values can be learned (Tezcan 1974 quoted in Şirin 1986).

In the light of the information above, first of all it is understood that values emerged as a result of the needs of the local communities. It is also clear that values which have been agreed on by the majority are called core or consensus values and they are vital for most character education programs. Different authors state related values such as honesty, trustworthiness, and tolerance as previously mentioned. The core values are basic values in the sense that diverse individuals perceive them the same, including supporters of dissimilar political movements. They are necessary to achieve character education and they are teachable both in terms of their importance and meaning. Tezcan agrees with Lickona that values can be learned and therefore taught. It is essential to remember that in character education, students are taught to be responsible for the consequences of their actions if they act against values.

Kirschenbaum agrees with the stress on basic values (1995 quoted in Cohen 1995): "Things are more moral, or more right, among other reasons because they're more consistent with values of respect, fairness, and justice. We have to help students understand that we can go back to commonly agreed-upon understandings of these basic values and moral principles, which they can use when making individual value decisions." In Huffman's view, middle and high school students need to spend more time engaging in moral reasoning and critical thinking (1994 quoted in Cohen 1995). He explains that time has to include helping them make their decisions about controversial matters on which school will not take a position. He also expresses that "Young children can usually concentrate on learning to choose between clear-cut right and wrong decisions, which are not true ethical dilemmas. Older students face values issues of increasing complexity." (Huffman 1994 quoted in Cohen 1995). An educational program called Human Values Education Program deals with five universal values (IDE 1996 quoted in Kulaksızoğlu \& Dilmaç 2000): love, reality, inner peace, correct behavior, and avoiding violence. The authors mention that it is necessary to connect these values with "related values" such as honesty, sharing, happiness, patience, courage, respect, pity, and considerate behavior. Gilness (2003) states that her students needed assistance so as to acquire universal values which would permit them to make ethical decisions.

When the emphasis on basic values is taken into account, Kirschenbaum shares the same ideas with the abovementioned authors and repeats the most frequent values, which are respect, fairness, and justice. In his view, students need help prior to making their individual value decisions. Likewise, Huffman defends the idea that students should spend enough time for moral reasoning and critical thinking because they will need to make decisions on controversial issues. Unlike young students, older ones (in other words high school students) will face ethical dilemmas eventually. Gilness agrees with him completely as she shares her observation and experience. When we look at the values listed by Kulaksızoğlu and Dilmaç, the similarity with the aforementioned values is obvious.

While giving information about an educational program called the Living Values, Arweck and Nesbitt (2004) explain that this program is based on 12 values: peace, respect, love, tolerance, honesty, humility, cooperation, responsibility, happiness, freedom, simplicity, unity. They add that according to the designers of this program, these values are universally acceptable and they should be encouraged in people so as to make the world a better place to live. Halstead defines values as "principles, fundamental convictions, ideals, standards or life stances which act as general guides to behavior or as reference points in decision-making or the evaluation of beliefs or action" (1996 quoted in Arweck \& Nesbitt 2004). In Arweck and Nesbitt's opinion, the values are a response to "the call for values" in a world in which children are influenced by social difficulties, violence, and a lack of respect. They are also an answer to educators and parents who ask for help in countering these changes. As Ashton and Watson express (1998), "no schooling of any kind can operate without values being conveyed". Doyle (1997) agrees by stating that "there is no such thing as a value-free school". Due to this, schools must reinforce virtues such as honesty, forbearance, toleration, respect for self and others, courage, and integrity (Doyle 1997).

As seen above, Arweck and Nesbitt introduce a list of values, which are the basis of an educational program. Moreover, these are universal according to the creators of this program as they report. Like Cohen, they repeat that these values have come onto the stage as a rescue due to the fact that negative changes had been affecting children for some time. The values are regarded as assistants to families and educationalists. As well as Ashton and Watson, Doyle echoes the statement that schools convey values and he further sees it is schools' duty to support them.

For Eisner (1994 quoted in McLaughlin 2005), "ethos refers to the underlying deep structure of a culture, the values that animate it, that collectively constitute its way of life". He believes that ethos is connected to the core values of the school. In Doyle's (1997) opinion, "values are the engine that defines and drives culture". As seen at the beginning of this paragraph, the set of ideas and moral attitudes that are typical of a particular group is defined and then the 
connection between the core values of a school and its ethos is underlined. When Doyle offers a definition of values, he means that school culture is defined and driven by values themselves. In short, it could be interpreted that concepts of the school culture, values of that school and moral attitudes of the same school are inseparable.

Willemse et al (2005) believe that teacher educators' teaching is always a moral activity. They state (2005) that "teacher educators express personal values in the way they relate to their students, and they must stimulate their student teachers to develop their own values and norms, and to become teachers who are aware of the ways in which they express their own values through their teaching." Moreover, they need to prepare candidate teachers to assist their students to improve values and norms, and prepare them for citizenship (Willemse et al 2005). In the Netherlands, teachers are expected to develop their awareness of values, be explicit about them, and create opportunities for students to improve their own sets of norms and values (Willemse et al 2005). Hansen (2001 quoted in Willemse et al 2005) states that teachers influence the values of students through the curriculum and instructional approaches. In addition, he mentions that "teachers feel compelled to enact qualities that they believe their students both want and need to see in them: confidence, poise, fairness, commitment, etc." (Hansen 2001 quoted in Willemse et al 2005).

According to the scientists above, there is always a moral activity that takes place at colleges of education. Teacher educators tell their students about their personal values and it is their obligation to encourage teacher candidates to develop their own values. When they prepare future teachers, they are careful to help them become teachers who are aware of the means through which they communicate their values. Hansen says that teachers influence their students' values by instructional methods and school subjects. Furthermore, these teachers act as role models for their students. Especially acting as role models is highly vital as teachers can and must transfer positive character traits by demonstrating good actions to the next generation's teachers.

In Sherman's (2005) view, "bodily comportment, respect, and kindness expressed in emotional demeanor, tone of voice, and gesture are all part of the proper exchange of values". She argues that classrooms are a place to model such exchanges and to consolidate the significance of social conduct which engages the whole person (Sherman 2005). Therefore, Sherman agrees with Hansen on the topic of teachers' being role models. She describes various ways of showing values on the part of teachers and also adds that it is a two-way experience since students too can display their values in the classroom.

According to Wringe (1998), the values that our actions reflect are placed at a deeper level of the self. He believes that "to have macho, philistine, or indeed egalitarian values is to want to act in certain ways, or to tend to do so automatically, and reflection upon one's obligations, legal or moral, may often restrain one from doing so." He defines values as judgments of approval, our supporting attitudes towards the abilities, characteristics and behaviors deserving admiration, praise or imitation or with which we would like to recognize ourselves. He argues that somebody's values represent what they consider as most significant when there is a serious or difficult situation and for which other things would finally be sacrificed. In his view, to change one's values might require us to change either a culture, or to remove them from their current social context. As he mentions, if this amendment is to be educational, it has to be done with a degree of knowledge of the process on the part of the people involved. Another issue he adds is that "our values are to be judged not by our words but by our actions and values are essentially social and positive".

It may be interpreted that our actions reflect our values as Wringe proposes. An expression of values is automatic actions, or willingness to act in some ways. For him, our judgments of approval are values briefly. When there is a challenging situation and when we would sacrifice other things for it, what we consider the most important is the values in his opinion. Changing values is extremely hard as he mentions. When an educational change is concerned for values, then it is absolutely essential to be knowledgeable about the process on the stakeholders' part. It is not questionable whether our actions judge our values. Besides, it must be remembered that values are basically hopeful and they exist for the society.

"Some colleges and universities have begun to place greater emphasis on student outcomes that concern public service, civic participation and leadership, and humane or ethical values and behavior" as Colby (2002) reports. This trend is visible in the increase of both curricular and extra-curricular programs that are planned to encourage the improvement of students' civic and moral responsibility (Colby 2002). Besides, she adds that national conferences are organized on university students' values (Colby 2002). Here, Colby observes that ethical values and behavior of students have started to receive attention from some higher education institutions. Such institutions have been trying to foster students' citizenship and ethical responsibility. Moreover, she has noticed that national symposia on the topic of university students' values are organized. These changes are all positive as they indicate that universities have grasped the importance of values and they are willing to educate their students in this respect as well by acting towards the goal of equipping their students with ethical values and moral responsibilities. 


\section{Values Education}

Arweck and Nesbitt (2004) state that "values-based education can be seen as a kind of tool-kit for children and young people as well as adults in thinking about the values in their lives, applying them in dealing with relationships and social situations, and shaping attitudes towards others, property, and social structures". According to Ashton and Watson (1998), values education must encourage an approach that is really educational, rather than dependent on authority structures. In Lovat's (2005) opinion, an environment has been created that is "more conducive to the acceptance of values education as a natural attachment to the roles of the teacher and the school". Furthermore, he explains that this environment provides conditions as a practical agency of moral formation.

The Adelaide Declaration includes that (1999 quoted in Lovat 2005), schooling is to offer young Australian students with a basis for moral, intellectual, spiritual, social, physical and aesthetic advancement whereas the Federal Government Values Education Study (DEST 2003 quoted in Lovat 2005) informs citizens that schools are not value-free areas of educational and social engagement that they are "as much about building character as equipping students with specific skills" and that "values education is an explicit goal aimed at promoting care, respect, and cooperation." Lovat (2005) reports that the National Framework for Values Education (2005) expresses that "values education reflects good practice pedagogy". He believes that values education will improve in students the type of communicative capacities, interpretative and control of negotiation which are in the center of a social conscience, and furthermore, the reflective and self-reflective development which is the "foundation of a personal morality."

Thanks to values education, Arweck and Nesbitt believe that people of all ages can think about the values in their lives, apply them, and shape their attitudes towards other people. Ashton and Watson warn that values education must not depend on any authority. In other words, it must not be done out of concerns regarding higher level educational bodies. Instead, the driving goal must be education itself. Lovat highlights that values education is natural in the school context when teachers' roles are taken into account. It is in line with the moral formation of students as the Adelaide Declaration emphasizes the moral improvement of students. Similarly, the Federal Government Values Education Study states that schools are value-laden and they are concerned with the building of character. As Lovat declares, values education and morality are undoubtedly interrelated.

Lovat (2005) argues that in values education, it is believed that teachers are capable of making a difference by engaging their students in the life-shaping and sophisticated learning of personal moral improvement. He (2005) concludes that with values education, teachers can form the kinds of relationships with their students that express their care and commitment and that become the foundation of building personal character. In summary, the moral development of students is realized through values education, and character formation takes place with the support of values education.

According to Muijen (2004), the idea of value education is in a long philosophical tradition, beginning from the Greek term paedeia (from which the word pedagogy originates) and ending in the Enlightenment thought and "ideal of a systematic improvement of our rational faculties, leading to the moral, cognitive and technical development of the individual and of society as a whole." She continues that the concept of value education is a necessary feature of a wider idea of development as a process of improving humans as a "whole person", including the spiritual, cultural, and political. In her view (2004), the following could be achieved with the help of value education: "the re-integration of a value perspective in science, technology and education, enhancing a sense of moral and social responsibility in questions of sustainable development, thus modestly contributing to a "re-valuation of our world"." To sum up, the moral advancement of a person is primarily aimed at in values education. However, as the ultimate goal, improving human beings as a whole person is set; meaning political, cultural, and spiritual dimensions. The moral responsibilities as well as a value perspective in education in addition to science and technology are objectives to be accomplished with the assistance of values education.

\section{Values Education and Character Education}

Vedder and Veugelers (1999 quoted in Willemse et al 2005) found many inter-related terms such as value education, character education, citizenship education, and religious education. These terms differ, for instance, in the degree to which they concentrate on personal or social values (Willemse et al 2005). Yet, there are similarities and one example was noted by Biesta and Miedema (2002 quoted in Willemse et al 2005): the word "pedagogy" is used to emphasize that "education" has a wider meaning than "training" or schooling". It also includes the teaching of norms and values as the authors explain. As literature suggests, there are many terms which are related to each other as the examples above. 
There are differences as well as resemblances between them. Milson and Mehlig (2002) state that "character education is commonly defined as the process of developing in students an understanding of, commitment to, and tendency to behave in accordance with core ethical values". Here, we can see a widely used definition of character education that shows its clear connection with values.

Cohen (1995) states that character educators defend a strategy of teaching core values that have been improved by community consensus. He mentions that "schools and districts are enlisting parent and community participation in the design and implementation of character education programs." Supporters of character education believe that the most succesful character education approches emphasize both curriculum and changing the culture of schools so as to make them reinforce positive character traits and values (Cohen 1995). In Cohen's view, character educators would like to develop the professional and economic prospects of their students and also advance the social and moral fiber of their communities. He quotes (1995) Kirschenbaum (1995): "I've never seen such a broad-based public concern about values and character in our society, and such a strong statement of desire to do something about it in our schools". According to the results of a survey that was conducted in Michigan among parents, public schools do not do enough to teach character and values (Cohen 1995). Cohen (1995) reports that defenders of character education think that character education is one method to win community support. He continues that the findings of repeated studies demonstrate that more than 90 percent of adults' opinion is that schools should teach noncontroversial values such as democracy and honesty. Kirschenbaum thinks (1995 quoted in Cohen 1995) that successful character education necessitates a mixture of inculcation, modeling and facilitating of values.

Cohen stresses the importance of the involvement of parents and community for the character education programs in schools, which is reasonable. Character education should not stand alone by itself as values and character traits are first transmitted by the family and then the society. Hence, their active participation is essential. Since graduates are natural members of the society, the moral values of students matter as today's students are actually the future of their community. Cohen reports some survey results and he would like to emphasize that teaching of values and good character traits was missing in parents' views. He quotes another author, Kirschenbaum who mentions the role of modeling, meaning teachers' considerable influence on their students and the significance of their acting as role models.

Strong data reinforce that it is necessary for parents to model and transmit values to their children (Schwartz 2000). However, Schwartz (2000) suggests an alternative opinion and states that character is not engraved by age 6, or even 16. He argues that it is possible to change and improve character. Arthur (2005) believes that "communication of values that help develop students' character takes place largely through the example of tutors". Likewise, Milson and Mehlig (2002) add that teachers are identified as an extremely important factor in the improvement of character in youth. Primary school teachers feel confident to be role models, discuss matters of right and wrong with students, and use strategies which could lead to positive changes in their students' character (Milson \& Mehlig 2002). They are certain that they are capable of encouraging traits such as responsibility, honesty, compassion, courtesy, and respect (Milson \& Mehlig 2002). Hesapçıoğlu (2004) states that education is a relationship between learners and teachers. In his view, education builds the value and moral world of learners. Through education, a learner constructs a moral and ethical nature (Hesapçıoğlu 2004).

Several authors above agree that character improves in later ages and teachers have great potential to transfer values from primary school to university. It is a fact that teachers are influential figures in our lives and when they act as exemplary agents, students benefit from them tremendously in terms of developing their own character. This is why teachers' responsibility is of utmost importance at all levels of educational institutions.

The types of educational impact which schools and teachers try to exert on students relate to several sorts of achievements and take a wide range of forms (McLaughlin 2005). McLaughlin (2005) mentions that the sorts of accomplishment on the part of students that are aimed at include "knowledge and understanding of various kinds and levels, dispositions, virtues, qualities of character, emotional responses, tendencies, skills, capacities and so forth." Again, McLaughlin agrees with former authors and he lists kinds of qualities which are passed on to students by their teachers and schools.

Doyle believes that schools shape character (1997). Moreover, he believes in the existence of good and bad values and claims that schools shape character for ill or good (Doyle 1997). In character education, "fundamental values must be internalized to the point of habituation" (Doyle 1997). In brief, the effect of schools on character is mentioned and the link between values and character traits is pointed out. It must be remembered though that values need to take the form of habits; in other words, they need to be expressed in actions that are automatically performed.

Character is defined by Lickona (1989 quoted in Howard et al 2004): "Character consists of values in action. Character has three interrelated parts: moral knowing, moral feeling, and moral behavior." Howard et al (2004) state that 
societies, families, and educators are interested in encouraging the improvement of character in children and over the years, this search has received various names such as values education, moral education, and character education. These authors provided a table that presents a taxonomy of programs considered to be character education (2004) and Table 1 shows six out of ten types of character education. Lickona agrees with Doyle on the subject of values in action while Howard et al echo Vedder and Veugelers when they list various terms that are found in literature.

Table 1: Partial Taxonomy of Character Education Programs

\begin{tabular}{|c|c|c|}
\hline Type & Major pedagogical approach & Example \\
\hline $\begin{array}{l}\text { Moral reasoning - } \\
\text { Cognitive } \\
\text { development }\end{array}$ & $\begin{array}{l}\text { Discussion of moral dilemmas facilitates } \\
\text { student development of moral reasoning } \\
\text { capacities }\end{array}$ & $\begin{array}{l}\text { Reasoning With Democratic Values: Ethical Problems in } \\
\text { United States History (Lockwood \& Harris, 1985); Just } \\
\text { Community Approach (Power, Higgins, \& Kohlberg, 1989) }\end{array}$ \\
\hline $\begin{array}{l}\text { Moral education - } \\
\text { Virtue }\end{array}$ & $\begin{array}{l}\text { Academic content (literature, history) used to } \\
\text { teach about moral traditions to facilitate moral } \\
\text { habits and internal moral qualities (virtues) }\end{array}$ & $\begin{array}{l}\text { The Book of Virtues (Bennett, 1993); Character Counts! } \\
\text { (Josephson Institute, 2001, 2002) }\end{array}$ \\
\hline $\begin{array}{l}\text { Life skills } \\
\text { education }\end{array}$ & $\begin{array}{l}\text { Practical skills (communication) and positive } \\
\text { social attitude (self-esteem) stressed }\end{array}$ & $\begin{array}{l}\text { Seattle Social Development Project of the University of } \\
\text { Washington Social Development Research Group (e.g., } \\
\text { Catalano \& Hawkins, 1996; Lonczak, Abbott, Hawkins, } \\
\text { Kosterman, \& Catalano, 2002) }\end{array}$ \\
\hline $\begin{array}{l}\text { Citizenship } \\
\text { training-Civics } \\
\text { education }\end{array}$ & $\begin{array}{l}\text { American civic values taught as a preparation } \\
\text { for future citizenship }\end{array}$ & We the People (from the Constitutional Rights Foundation) \\
\hline Caring community & $\begin{array}{l}\text { Caring relationships fostered in the classroom } \\
\text { and school }\end{array}$ & $\begin{array}{l}\text { Child Development Project (1996) (from the Developmental } \\
\text { Studies Center); Community of Caring (from the Joseph P. } \\
\text { Kennedy Jr. Foundation); Educating Moral People (Noddings, } \\
\text { 2002a) }\end{array}$ \\
\hline $\begin{array}{l}\text { Ethics-Moral } \\
\text { philosophy }\end{array}$ & Ethics of morality explicitly taught & $\begin{array}{l}\text { Moral Questions in the Classroom (Simon, 2001); Philosophy } \\
\text { in the Classroom (e.g., Lipman, 1988); and Socratic Seminars } \\
\text { (e.g., Adler, 1982; Gray, 1989; Strong, 1996) }\end{array}$ \\
\hline
\end{tabular}

Source: Howard et al. (2004) Politics of Character Education, pages 197 \& 198

According to Howard et al (2004), character education may refer to one of three approaches: caring, traditional character, and developmental. The first and third approaches use the term moral education and the authors use the second one in reference to the narrow approach. They state that traditional character education emphasizes transmitting virtues (2004). In Bush's opinion (2002 quoted in Howard et al 2004), the primary unit of traditional character education is the family: "Family is the first place where values are learned." As can be seen, Howard et al categorized character education into three groups. They quote Bush in order to remind everyone that the birth place of values to be taught is the family, which is an unarguable truth.

Nijhuis et al (2005) express that "in moral education, his colleagues and himself distinguish between three approaches: communication about values, transfer of values, and presentation of values." In their study, they found two approaches among trainee teachers: A combination of transfer and communication of values, which they called value orientation, and value presentation. A close term to character education is moral education as was previously mentioned and here the connection between values and morals is apparent once more. The results of a study about moral education by Nijhuis et al display that trainee teachers focus on value orientation and value presentation.

According to the research findings of an empirical study which involved university students' responses to an openended question regarding character education, one of the categories that emerged as a result of content analysis was the connection between values system along with morality and character education (Sılay 2013a). The highest number of responses was from the students of education college; however, this was the least mentioned category among all students at four types of colleges: education, arts and sciences, engineering, economics and administrative sciences. A possible explanation of the reason could be the disappearance of many values in today's society and hence, the fact that students do not think much about them. That is to say, because students do not remember morality and values system often, they probably do not relate these concepts to character education (SIlay 2013a). If values do not take part in the society we live, we inevitably tend to forget their existence. In order to notice them, we need to feel that they relate to our lives. The author proposes some non-credit elective courses to be offered at universities such as "Moral philosophy and 
character", "Character concept in psychology", "Values and character link", and "Work ethics and character". This proposition was felt necessary as a response to the lack of values in students' eyes. Such courses could act as a starting point to convey character education along with virtues within the curriculum at tertiary education. They may be piloted in the beginning and the content could vary in terms of focus topics.

A related empirical study following the one above was conducted through semi-structured face-to-face interviews with academics at the same four types of colleges (Sılay 2013b). The sixth interview question was in which of the four colleges, most academics believe that character education is applied in higher education and why they believe so. The first two colleges were education and arts and sciences. The reasons could be the fact that character education is a natural subject of colleges of education and colleges of arts and sciences are concerned with humanities and included values (SIlay 2013b). The result was not unexpected when the nature of these colleges is considered. By the term, character education directly suggests colleges of education. As for the colleges of arts and sciences, values, character, and virtues are subjects of the humanities such as philosophy, psychology, and sociology from their own angles. Therefore, these colleges were foreseen as well.

The Character Education Partnership announces in its Eleven Principles of Effective Character Education that there are "widely shared core ethical values that form the basis of good character and that schools must explicitly encourage those values" (Lickona, Schaps \& Lewis 2002 quoted in Hoge 2002). In Table 2, Hoge (2002) shows the endorsed values of the eleven principles. In short, the core values' direct link with good character and values has been restated. The above-mentioned authors report that core values need to be encouraged at schools clearly and directly.

Table 2: Values Endorsed in the Eleven Principles of the Character Education Partnership

\begin{tabular}{|l|l|}
\hline \multicolumn{1}{|c|}{ Explicitly Endorsed Values } & \multicolumn{1}{|c|}{ Implicitly Endorsed Values } \\
\hline Caring & Individualism \\
Honesty & Human dignity \\
Fairness (justice) & Common good \\
Responsibility & Constitutional rights \\
Respect for self and others & Citizenship responsibilities \\
Civility & Involvement / participation \\
Cooperation & Inclusiveness \\
Obedience to authority & Diversity \\
Nonviolence & Communicativeness \\
Abstinence & Trust \\
Meaningful and challenging academic & Leadership \\
curriculum/importance of knowledge & Appreciation of community \\
& \\
\hline
\end{tabular}

Source: Hoge, J. D. (2002) Character education, Citizenship Education, and the Social Studies, page 105

\section{Conclusion}

When the points of view of different academics are considered on the subject of values education and its relationship with character education, repeated themes appear. For instance, most argue for teachers' impact on their students' character formation and that they do teach values and positive traits through their behavior. Therefore, they attach great importance to teachers' acting as role models. In my opinion, the correctness of teachers' actions is definitely crucial. Since they are the second force following families in terms of helping students acquire values, they must be extremely careful when they interact with their students.

As to the issue of values, those that are agreed on by the majority of a society need to be taken into account by educational institutions. Evidently, some adjustments will need to be made in time when different needs arise within the same society. Focussing on noncontroversial ones will prevent any kind of opposite poles though. So as to embrace students as a whole, such a peace seeking and inclusive approach should be adopted. I would suggest these values as the basic values for the society I live in at present: respect, responsibility, justice, courage, sharing, humility, and tolerance.

With regard to the role of higher education in the context of values education, I believe that academics should not give up trying to affect their students positively. The reason for the existence of universities is not solely producing science and conducting research. It must not be forgotten that academics are both researchers and teachers. Hence, 
giving values education as well as character education needs to be regarded among their responsibilities, especially when it is clear that tertiary education is the final step of individuals as students before starting their professional lives.

To conclude, values are strongly held in character education and this current has much in common with values education. As well as schools, higher education institutions need to comprehend the necessity of applying values education for the sake of their students and their own future. It is hoped that there will be more researches conducted on this topic in various countries in the near future.

\section{References}

Arthur, J. (2005). Student character in the British university. In J. Arthur, \& K. E. Bohlin (Eds.), Citizenship and higher education the role of universities in communities and society (pp. 8 - 32). Oxon: Routledge.

Arweck, E. \& Nesbitt, E. (2004). Values education: the development and classroom use of an educational programme. British Educational Research Journal, 30 (2), 245 - 261.

Ashton, E. \& Watson, B. (1998). Values education: a fresh look at procedural neutrality. Educational Studies, 24 (2), 183 - 193.

Cohen, Philip, (1995), The content of their character: Educators find new ways to tackle values and morality. [Online] Available: http://www.ascd.org/publications/curriculum- update/spring1995/The-Content-of-Their-Character.aspx (April 6, 2013)

Colby, Anne, (2002), Whose values anyway? Journal of College and Character, 3 (5). [Online] Available: http://www.degruyter.com /view/j/jcc.2002.3.5/jcc.2002.3.5.1322/jcc.2002.3.5.1322.xml

(April 7, 2013)

Doyle, D. P. (1997). Education and character - a conservative view. Phi Delta Kappan, 78 (6), 440 - 443.

Gilness, J. (2003). Classroom practice - how to integrate character education into the curriculum. Phi Delta Kappan, 85 (3), 243 - 245.

Hesapçıŏlu, M. (2004). Eğitim nedir? Cumhuriyet Gazetesi, 30 Nisan, 28695, 2 \& 8.

Hoge, J. D. (2002). Character education, citizenship education, and the social studies. The Social Studies, 93 (3), 103 - 108.

Howard, Robert W., Berkowitz, Marvin W. \& Schaeffer, Esther, F., (2004), Politics of character education. Educational Policy, 18 (1). [Online] Available: http://dev.csufresno.edu/kremen-dev/bonnercenter/documents/Politics.pdf (April 6, 2013)

Kulaksızoğlu, A. \& Dilmaç, B. (2000). İnsani değerler eğitimi programı. Marmara Üniversitesi Atatürk Eğitim Fakültesi Eğitim Bilimleri Dergisi, 12, 199 - 208.

Lovat, Terence, (2005), Values education and teachers' work: a quality teaching perspective. [Online] Available: http://cmslive.curriculum.edu.au/verve/_resources/Values_Conf_020505_forum_address_Lovat.pdf (April 6, 2013)

McLaughlin, T. H. (2005). The educative importance of ethos. British Journal of Educational Studies, 53 (3), 306 - 325.

Milson, A. J. \& Mehlig, L. M. (2002). Elementary school teachers' sense of efficacy for character education. The Journal of Educational Research, 96 (1), $47-53$.

Muijen, H. (2004). Integrating value education and sustainable development into a Dutch university curriculum. International Journal of Sustainability in Higher Education, 5 (1), 21 - 32.

Nijhuis, E., Hermans, C. A. M. \& Wils, J - P. (2005). Religion and moral education: empirical research into the moral consciousness of trainee teachers in the Netherlands. Journal of Empirical Theology, 18 (1), 48 - 73.

Robson, C. (2000). Real world research. A resource for social scientists and practitioner-researchers. Oxford: Blackwell.

Schwartz, A. J. (2000). It's not too late to teach college students about values. The Chronicle of Higher Education, 46 (40), A68.

Schwartz, A. J. (2005). Searching for a moral North Star during the college years. In J. Arthur \& K. E. Bohlin (Eds.), Citizenship and higher education the role of universities in communities and society (pp. $65-73)$. Oxon: Routledge.

Sherman, N. (2005). Of manners and morals. British Journal of Educational Studies, 53 (3), 272 - 289.

Silay, N. (2013a). Character education at universities. Journal of Educational and Social Research, 3 (1), 43 - 50.

Silay, Nur, (2013b), Character education for university students. European Journal of Educational Studies, 5 (1), 111 - 121. [Online] Available: http://ozelacademy.com/ejes.htm (April 6, 2013)

Şirin, A. (1986). Gençlerin değerler sıralaması üzerine bir araştırma. Yayınlanmamış Yüksek Lisans Tezi, Marmara Üniversitesi, Sosyal Bilimler Enstitüsü, İstanbul.

Willemse, M., Lunenberg, M., \& Korthagen, F. (2005). Values in education: a challenge for teacher educators. Teaching and Teacher Education, 21, $205-217$.

Wringe, C. (1998). Reasons, values and community in moral education. British Journal of Educational Studies, 46 (3), 278 - 288. 